Panda, R., \& Bag, D. (2020). A Simple Linear Test of the Integration in Corporate Bond Markets. Copernican Journal of Finance \& Accounting, 9(4), 77-85. http://dx.doi.org/10.12775/ CJFA.2020.022

\author{
RuChIRA PANDA* \\ National Institute of Technology Rourkela \\ Dinabandhu BaG ${ }^{* *}$ \\ National Institute of Technology Rourkela
}

\title{
A SIMPLE LINEAR TEST OF THE INTEGRATION IN CORPORATE BOND MARKETS
}

Keywords: integration, yield, forecast, markets.

\section{J E L Classification: G15, G12, E44.}

Abstract: The purpose of this article is to identify the key elements of market determinants of bond yield and the external borrowing environment. A reasonably integrated bond market is safer for both investors as well as issuers. It assesses the robustness of integration in corporate bond yields. Research method applied in this particular study includes the overview of theoretical concepts, literature review and analysis of secondary yield data. The results revealed significant differences between the sensitivity of coupon bonds and zero coupon bonds. It demonstrated stronger relationship between bond yield, money markets and external credit markets, respectively. Modern bond portfolios can be constructed focusing on factors beyond coupon rates, duration and credit rating, respectively. The outcome or further research could focus on examining alternate anchors against secured overnight short term financing rates.

Date of submission: February 8, 2021; date of acceptance: March 3, 2021.

* Contact information: rk6385@gmail.com, Research Scholar, School of Management, National Institute of Technology, Rourkela, India Pin: 769008, phone: 919438715089; ORCID ID: https://orcid.org/0000-0001-6283-5052.

** Contact information: dinabandhu.bag@gmail.com, Research Scholar \& Faculty, School of Management, National Institute of Technology, Rourkela, India Pin: 769008, phone: 916612462803; ORCID ID: https://orcid.org/0000-0001-9736-1299. 


\section{INTRODUCTION}

Globally, the 10-year Treasury yield has retracted from a record low in 2020 and the US 10 year treasury yield had crossed $1.64 \%$ in 2021 . The flatter yield curve could have meant the corporates to avail bonds more than bank lending. Are the corporate bond yields strongly related to the interbank credit markets? This paper focusses on market determinants of bond yield and the external borrowing environment. For fixed-income securities, yield-based measures are more suitable to test the law of one price. Cappiello, Engle and Sheppard (2003) and Cifarelli and Paladino (2006) had explored bond movement in international bond markets. Barr and Priestley (2004) assessed the degree of integration of the US, UK, Japan, Germany and Canada bond markets. Barr and Priestley (2004) demonstrated that countries with high budget deficits such as Portugal, Ireland, Turkey, Italy and Spain had also seen downgrades. Corradin and Rodriguez-Moreno (2016) demonstrated that the overall ECB collateral related factors explained a good share of the variation in the bond yield basis and cross country dispersion in yield basis. Increasing concern about the ability of some governments' to repay their debt, which resulted in widening of government bond yields. The construction of integration measures for the money and government bond markets is facilitated by the presence of homogeneous assets. However, there are differences among assets in credit markets. Given comparable maturities, interest rate differences between borrowers of the similar risk class are a direct measure of the degree of integration. Assuming the law of one price holds, the yields in perfectly integrated markets should be equal to each other. Corporate bonds are generally not homogeneous and differ in their cash flow structure, liquidity, sector profile, and credit rating. Similarly, a rise in exchange rates could reflect corresponding activity in domestic bond markets due to lower yield rates.

During the 1990s, the historical yields across domestic markets, the average coupon rates varied between 50 basis points to 500 points (ECB). During the same period the central bank rates remained higher than the average coupon rates (USFED). The corresponding bond yield did vary between $0.8 \%$ to $22 \%$ (NSE, 2016), which could be much lower than the average prime lending rates (PLR) of top banks during the same period Das (2015). The reasons for the lower deviation in bond yields could be attributed to the integration of bond markets with money markets, external credit markets, forex markets or 
commodity markets, respectively. The aim of this paper is to test the major hypothesis on the prevalence of the law of one price for bond yield using test data.

\section{RESEARCH METHODOLOGY AND RESEARCH PROCESS}

As a fallout of the global financial crisis the responses within the eurpean monetary system, and its consequential impact on members of the european members have been examined by Pys (2017), Kasperowicz-Stępień (2015), respectively. Later Maciejczyk-Bujnowicz (2016), have looked at the integration aspects of capital flows within the european system. The issues of integration between bond yield and related indicators have been discussed in Bekaert and Harvey (1997), Ng (2000), Fratzscher (2001), and Baele (2005), Corradin and Rodriguez-Moreno (2016), Hui, Lo and Chau (2017) who have adopted empirical models using test data for many countries. These works have implemented yield changes signals as proxies against the impact of common news and find that global news factors significantly affect equity returns. Hui et al. (2017) studied the influence of exchange rate toward sovereign bond yield in several countries including Brazil, Colombia, Mexico, Philippines, Russia, and Turkey. Hui et al. (2017) showed that exchange rate affects sovereign bond yield. Eckhold (1998) looked at the influence of exchange rate, inflation, and interest rate on bond yield of New Zealand. Shah (2019) have tested the integration of financial and Non-Financial Risks for asian economies. Mahanti, Nashikkar, Subrahmanyam, Chacko and Mallik (2008) had presented that volume and trading activity are the critical determinants of Bond yield in India. There are few works that has tested on the impact of forex markets, commodity and external credit markets on bond yields. Heston and Rouwenhorst (1994) and Annaert and De Ceuster (2000) proposed a simple linear model of the relationship between the bond characteristics and market situations. The linear tests are well established, easy to understand and implement and can provide reasonable predictions. Following, Heston and Rouwenhorst (1994) and Annaert and De Ceuster (2000), we denote the yield measure as follows;

$$
\mathrm{YTM}_{\mathrm{i}, \mathrm{t}}=\alpha+\sum_{\mathrm{i}} \beta_{\mathrm{i}} \mathrm{X}_{\mathrm{i}, \mathrm{t}}+\sum_{\mathrm{i}} \delta_{\mathrm{i}} \mathrm{Z}_{\mathrm{i}, \mathrm{t}}+\sum_{\mathrm{i}} \gamma_{\mathrm{i}} \mathrm{F}_{\mathrm{i}}+\varepsilon_{\mathrm{i}, \mathrm{t}}
$$

Where $\mathrm{YTM}_{i, t}$ is the yield of bond $\mathrm{i}$ in time $\mathrm{t}$, 
$\mathrm{Xs}$ are the bond attributes, Zs include the money market indicators and, $\mathrm{F}_{\mathrm{i}} \mathrm{S}$ are the credit market, forex market, economic indicators or external market indicators. The yield of the corporate bond depends on credit rating, time to maturity, liquidity and cash flow (Baele, 2005). Chordia, Goyal, Nozawa, Subrahmanyam and Tong (2017) mentioned the significance of credit quality on corporate bond premiums. Mahanti et al. (2008) mentioned the importance of market activity indicators on bond premiums. Since few works has put attention on the forex markets, and external credit markets, we induct REER (effective exchange rate), which could influence the yield, since external borrowings and flows would moderate domestic bond activity.

The choice of variables is motivated by standard sources of market and economic data. For coupon bonds, $\mathrm{X}_{\mathrm{i}} \mathrm{s}$ include, namely, coupon rate, Maturity, Rating, etc. The $\mathrm{Z}_{\mathrm{i}} \mathrm{s}$ reflect the money market activities, Combined Total Liabilities of the Federal \& States (INR Crores), Total Bonds Volume (Rupees crore), and Total Liquidity (Rs Crore). To incorporate economic or market indicators we include, Average Gold Price Mumbai (INR per 10gms), Real effective Exchange Rate (REER), LIBOR rate (USD), Repo Rate, etc. The annual economic indicators are, GDP at Factor Cost, GDP growth, Per Capita GNP at factor cost, Per Capita GNP Growth, Foreign direct investment (FDI), foreign portfolio investment (FPI), Splashed Growth rate of Industrial Production, Annual Average of stock index (NIFTY, BSE), annual inflation (WPI), etc.

Table 1 provides descriptive statistics of the dataset used. The sample comprises of yield data from the archive period from January 1999 to December 2016. Secondary market trading in corporate bonds executed over the counter (OTC), but these trades are reported to multiple platforms NSE, BSE and FIMMDA. The bond characteristics data includes issue characteristics, credit rating, last trading price, etc. The market variables and economic indicators include published data from IMF and the central bank (RBI). The independent variables covered included available periodic return information from asset markets such as debt, gold, forex, stocks, etc. It also includes periodic industrial and growth variables of IIP, GDP, average inflation, etc. 
Table 1. Descriptive statistics

\begin{tabular}{|c|c|c|c|c|}
\hline Variable & Mean & STD. & Min. & Max. \\
\hline Coupon (\%) & 8.08 & 3.33 & 0.00 & 15.20 \\
\hline YTM (Yield to maturity) & 8.1 & 1.8 & 0.8 & 22.0 \\
\hline Maturity (Months) & 75.43 & 40.47 & 1.90 & 228.00 \\
\hline Total_Bonds (INR Millions) & 18931.70 & 16142.02 & 4603.23 & 50927.60 \\
\hline LIBOR (\%) & 2.22 & 2.24 & 0.09 & 6.69 \\
\hline Repo_rate (\%) & 6.75 & 1.05 & 4.85 & 8.36 \\
\hline REER (Exchange rate) & 95.00 & 2.95 & 90.54 & 103.17 \\
\hline FDI (INR MILLIONS) (Direct Investment) & 71612.90 & 61885.57 & 8871.10 & 170106.05 \\
\hline FPI (INR_MILLIONS) (portfolio investment) & 45190.36 & 60168.25 & -60437.10 & 145840.20 \\
\hline GDP_at_Factor_Cost (INR MILLIONS) & 3133004.81 & 886236.00 & 2111199.16 & 4633949.90 \\
\hline GDP_growth (\%) & 6.65 & 1.81 & 3.61 & 9.12 \\
\hline Per_Capita_GNP_at_factor_cost & 28044.29 & 6378.02 & 20936.10 & 38726.75 \\
\hline Per_Capita_GNP_Growth (\%) & 5.04 & 1.90 & 2.09 & 7.79 \\
\hline Splashed_Growth_rate_of Industry (\%) & 6.46 & 3.23 & 2.38 & 14.44 \\
\hline Annual_Average_of_Stock Index (BSE) & 4419.12 & 2892.09 & 1508.32 & 9348.19 \\
\hline Annual_Average of_Stock Index (NIFTY) & 2575.83 & 1592.01 & 984.30 & 5304.33 \\
\hline Gold_price_Mumbai (INR per 10g) & 8543.54 & 4924.71 & 4173.92 & 18265.75 \\
\hline Combined_Total_Liabilities (INR MILLIONS & 69.54 & 5.04 & 61.66 & 77.05 \\
\hline Total_Liquidity (INR MILLIONS) & 11349700.35 & 6780900.22 & 4070406.10 & 23551081.40 \\
\hline Inflation (WPI) & 0.00 & 0.10 & -0.48 & 0.10 \\
\hline
\end{tabular}

S o u r c e : National Stock Exchange (archives) NSE, \& RBI.

Table 1 shows the variation in yield from $0.8 \%$ to $22.0 \%$ in the sample. It also shows the LIBOR varied from $0.09 \%$ to $6.69 \%$. Further the REER varies from 90.54 to 103.17 , alongside the Gold_price_Mumbai (INR per_10g ) from INR 4173.92 to INR 18265.75 , respectively. 


\section{THE RESULTS AND CONCLUSIONS OF THE RESEARCH PROCESS}

This paper produce a test of the law of one price in credit markets and analyzed yield based integration to demonstrate that corporate bond yields are significantly determined by the credit markets. Owing to Heston and Rouwenhorst (1994), and Annaert and De Ceuster (2000), the robustness tests of linearity were carried out to the sample.

The results of the two regression models are presented in table 2 below, for both coupon and zero coupon bonds, separately. The first model comprises the sample of zero coupon bonds and the second model includes the coupon bonds.

Table 2. Model Parameter Estimates

\begin{tabular}{|c|c|c|c|c|c|c|c|c|}
\hline \multirow[t]{2}{*}{$\begin{array}{c}\text { Dependent Varia- } \\
\text { ble=YTM }\end{array}$} & \multicolumn{4}{|c|}{$\begin{array}{c}\text { Model I: } \\
\text { Bond Type }=\text { Zero Coupon }\end{array}$} & \multicolumn{4}{|c|}{$\begin{array}{c}\text { Model II : } \\
\text { Bond Type }=\text { Coupon }\end{array}$} \\
\hline & Beta & $\mathrm{t}$-Value & P-Value & VIF & Beta & t-Value & P-Value & VIF \\
\hline Intercept & -1.1735 & -0.44 & 0.6601 & & -4.1109 & -0.63 & 0.5278 & \\
\hline Premium & 0.2597 & 4.85 & $<.0001$ & 1.11 & 0.3401 & 2.45 & 0.0143 & 1.00 \\
\hline Maturity & -0.0264 & -2.15 & 0.0316 & 1.08 & 0.0837 & 8.14 & $<.0001$ & 1.51 \\
\hline TOTAL_LIQUIDITY & $-2.97 \mathrm{E}-07$ & -1.77 & 0.0772 & 1.11 & $-1.60 \mathrm{E}-07$ & -1.61 & 0.1074 & 1.00 \\
\hline REER & & & & & 0.1043 & 1.71 & 0.0881 & 1.51 \\
\hline DW (Durbin) & None & & & 196 & 1 & & & 2.09 \\
\hline Lag (M) & & & & 2 & & & & 3 \\
\hline$R^{2}$ & & & & 0.45 & & & & 0.048 \\
\hline MSE & & & & 1.07 & & & & 1.50 \\
\hline
\end{tabular}

Note:

1. Multi-collinearity (VIFs) are lower.

2. The null hypothesis of endogeneity is rejected.

3. P-value of $<0.0001$ implies significance at $99.99 \%$.

S o u r c e : author's estimates from NSE Archives.

As shown above, the first model identifies the significant variables, namely, premium (difference between Average Repo Rate over average Libor rate), and Maturity, respectively. The higher premium due to larger difference between 
the average repo rate and the libor rate implies that yields are closely related with external credit markets. Similarly, the variable of Maturity is strongly sensitive to zero coupon yields and much lower impact on coupon yields. This complies with the convex nature of yields. The variable of Total_Liquidity is negatively significant which implies the upside impact of liquidity on yields. The rising total liquidity in the bond market is an indicator of the rising activity of bond market participants. The second model finds two variables, namely, REER (Real Effective Exchange Rates) and TOTAL_LIQUIDITY barely significant. For coupon bonds, we find the impact of premium on yields higher than the impact of premium for zero coupon yields. Similarly, for coupon bonds, we find the maturity impacts the yield higher than zero coupon bonds. Further our findings in consonance with Chordia et al. (2017) who suggest that bonds portfolios can focus on factors beyond duration and rating. Our findings are in consonance with Houweling and van Zundert (2017) who suggest creating momentum portfolios based on timeliness. We do not concur with Mahanti et al. (2008) who presented that changes in volume and trading activity are the most important. Of late, central banks (e.g., RBI in India (RBI)) had notified their domestic corporates to relook at their current funding structure and anchor to LIBOR. The relationship from the bond yield with REER lies along the lines with the portfolio balance theory of Pilbeam (2006) and Wang (2009). As a matter of fact, to construct a portfolio in a use case of these findings, an investor can create a bond portfolio of zero coupon bonds by selecting relatively longer maturity scrips during the phase of swings in libor, assuming that LIBOR rates are never manipulated. The limitation is it does not cover longitudinal time series data for longer years to arrive at the robustness of the findings to detect gauge the regulatory anchor which is used to discourage foreign borrowings. An insignificant pitfall of linear tests is that they ignore the presence of non-linearity in empirical specifications and other associated phenomenon of bi-directional causality, endogeneity, etc. It also relies on LIBOR rates which have seen scandals under investigation by Bank of England (2017). Schrimpf and Sushko (2019) suggests that the alternatives of unsecured money market rates used by banks to raise wholesale funding from non-banks such as MMFs is an attempt towards arriving at mix and match of both tenors and yields. The alternatives of unsecured money market rates to raise wholesale funding from non-banks such as MMFs could also reflect variations in marginal funding costs for domestic corporates. Future research, must endeavor examining secured overnight financing rate (SOFR) as its alternative. 


\section{REFERENCES}

Annaert, J., \& De Ceuster, M.J.K. (2000). Modelling European Credit Spreads. Deloitte \& Touche Research Report.

Baele, L. (2005). Volatility Spillover Effects in European Equity Markets, Journal of Financial and Quantitative Analysis, 40(2), 373-401.

Bank of England (2017). The future of LIBOR, Governor speech UK, https://www.fca. org.uk/news/speeches/the-future-of-libor (accessed: 21.03.2018).

Barr, D.G., \& Priestley, R. (2004). Expected returns, risk and the integration of international bond markets. Journal of International Money and Finance, 23, 71-97.

Bekaert, G., \& Harvey, C. (1997). Emerging equity market volatility. Journal of Financial Economics, 43(1), 29-77,

Cappiello, L., Engle, R., \& Sheppard, K. (2006). Asymmetric dynamics in the correlations of global equity and bond returns. Journal of Financial Econometrics, 4, 537-572.

Chordia, T., Goyal, A., Nozawa, Y., Subrahmanyam, A., \& Tong, Q. (2017). Is the CrossSection of Expected Bond Returns Influenced by Equity Return Predictors? Journal of Financial and Quantitative Analysis, 118-132.

Cifarelli, G., \& Paladino, G. (2006). Volatility co-movements between emerging sovereign bonds: Is there segmentation between geographical areas? Global Finance Journal, 16, 245-263.

Corradin, S., \& Rodriguez-Moreno, M. (2016). Violating the law of one price: the role of non-conventional monetary policy. Working Paper Series European Central Bank, 1927.

Das, S. (2015). Monetary Policy in India: Transmission to Bank Interest Rates. IMF Working paper 15/129, International Monetary Fund, Washington D.C.

Eckhold, K.R. (1998). Determinants of New Zealand Bond Yields. Reserve Bank of New Zealand Discussion Paper, G98/1..

Fratzscher, M. (2001). Financial Market Integration in Europe: on the effects of EMU on Fratzscher, M. (2001). Financial Market Integration in Europe: on the effects of EMU on Stock Markets. International Journal of Finance and Economics, 7(3), 165-193.

Heston, S. L., \& Rouwenhorst, K.G (1994). Does Industrial Structure Explain the Benefits of International Diversification?, Journal of Financial Economics, 36, 3-27.

Houweling, P., \& van Zundert, J. (2017). Factor Investing in the Corporate Bond Market. Financial Analysts Journal, 73(2), 100-115.

Hui, C.-H., Lo, C.-F., \& Chau, P.-H. (2017). Exchange Rate Dynamics and US Dollar-Denominated Sovereign Bond Prices in Emerging Markets. North American Journal of Economics and Finance, 44, 109-128.

Kasperowicz-Stępień, A. (2015). The Fiscal Challenges Of Polish Integration with The Euro Area. Coppernican Journal of Finance \& Accounting, 4(1), 83-96. http://dx.doi. org/10.12775/CJFA.2015.006. 
Maciejczyk-Bujnowicz, I. (2016). Capital Flows in European Union on the Basis of International In-vestment Position - Selected Aspects. Copernican Journal of Finance \& Accounting, 5(1), 157-172. http://dx.doi.org/10.12775/CJFA.2016.009.

Mahanti, S., Nashikkar, A., Subrahmanyam, M., Chacko, G., \& Mallik, G. (2008). Latent liquidity: A new measure of liquidity, with an application to corporate bonds. Journal of Financial Economics, 88(2), 272-298.

National Stock Exchange (2016). Archives of Daily/Monthly Reports, Listed Bonds, NSE, Mumbai, https://www1.nseindia.com/archives/archives.htm, (acessed: 28.6.2016).

$\mathrm{Ng}, \mathrm{A}$. (2000). Volatility spillover effects from Japan and the U.S. to the Pacific-basin. Journal of International Money and Finance , 19, 207-233.

Pilbeam, K. (2006). International Finance (3rd Ed. ). New York: Palgrave Macmillan.

Pys, J. (2017). Robustness of the Bank Resolution Framework in the European Union. Copernican Journal of Finance \& Accounting, 6(1), 77-87. http://dx.doi.org/10.12775/ CJFA.2017.005.

Reserve Bank of India (2014). Report of the Committee on Financial Benchmarks, RBI, Mumbai, https://www.rbi.org.in/scripts/PublicationReportDetails.aspx?ID=761, (accessed: 29.6.2016).

Reserve Bank of India (2016). Handbook of Statistics on Indian Economy, RBI, Mumbai, https://www.rbi.org.in/Scripts/AnnualPublications.aspx?Indian\%20Economy (accessesd: 29.6.2016).

Schrimpf, A., \& Sushko, V. (2019). Beyond LIBOR: A Primer on the New Benchmark Rates. BIS Quarterly Review, 29-52.

Shah, S.A.A. (2019). Integration Of Financial Risks With Non-Financial Risks: An Exploratory Study From Pakistani Context. Copernican Journal of Finance \& Accounting, 8(2), 49-65. http://dx.doi.org/10.12775/CJFA.2019.008.

Wang, P. (2009). The Economics of Foreign Exchange Market and Global Finance (2nd Ed.). Berlin: Springer-Verlag. 